\title{
The Use of Bacterial Larvicides in Mosquito and Black Fly Control Programmes in Brazil
}

\author{
Lêda Regis ${ }^{+}$, Sinara B da Silva, Maria Alice V Melo-Santos
}

Departamento de Entomologia, Centro de Pesquisas Aggeu Magalhães-Fiocruz, Caixa Postal 7472, 50670-420

Recife, PE, Brasil

Bacillus spp. based larvides are increasingly replacing, with numerous advantages, chemical insecticides in programmes for controlling black fly and mosquito populations. Brazil was among the pioneers in adopting Bacillus thuringiensis israelensis (B.t.i) to control black flies. However, the major current mosquito control programme in Brazil, the Programme for Eradication of Aedes aegypti launched in 1997, only recently decided to replace temephos by B.t.i based larvicides, in the State of Rio de Janeiro. In the last decade, works developed by research groups in Brazilian institutions have generated a significant contribution to this subject through the isolation of $\mathrm{B}$. sphaericus new strains, the development of new products and the implementation of field trials of Bacillus efficacy against mosquito species under different environmental conditions.

Key words: biological vector control - Bacillus sphaericus - Bacillus thuringiensis israelensis - Culicidae Simuliidae

Two important events in the 20th century history of vector control can be highlighted: the first one was the Global Program for Malaria Eradication based on vector control using very large amounts of DDT worldwide. This program, launched in 1955, had its apex in 1961-1962 resulting in a dramatic reduction of malaria incidence. A strong recrudescence occurred, however, in the following years. Vector population recovery, mainly due to resistance to DDT in Anopheles populations as well as DDT's lack of selectivity affecting non-target populations - including mosquito competitors, predators and pathogens - soon reversed early success. The urgent need for alternative tools to fight vector populations became then evident.

The second important event was the discovery, in 1964, of a mosquitocidal strain of Bacillus sphaericus (B.s) (Kellen \& Meyers 1964) followed by the identification of several more active strains and by the isolation of a new variety of $B$. thuringiensis (B.t) (Goldberg \& Margalit 1977) designated as B. t. israelensis (B.t.i) (de Barjac 1978), toxic to mosquito and black flies larvae. Highly toxic

\footnotetext{
This work was sponsored by UNPD/World Bank/WHO/ TDR, CNPq and Capes/Facepe.

${ }^{+}$Corresponding author. Fax: +55-81-453.2449

E-mail: leda@cpqam.fiocruz.br

Received 7 August 2000

Accepted 4 September 2000
}

to the target organisms, these spore forming bacteria are able to be mass produced, stored, easily transported and applied. Their larvicidal activity is due to large amounts of crystal proteins produced during sporulation and transformed into toxins under specific conditions after ingestion by larvae of certain insect species. Their selectivity is determined by both the structure of the proteins produced by the bacterium strain and the presence of proteolytic enzymes and receptor in the host larvae midgut. The importance of these findings was prompted recognized by scientists and a vast increase in publications relating to these bacteria has been seen since 1980.

Only two years after its discovery B.t.i was tested against the Simulium damnosum complex and appeared as a solution to the problem of Simulium populations resistance to organophosphate larvicides in the Onchocerciasis Control Program (OCP) in West Africa (Guillet et al. 1990). A commercial formulation was already available in 1981 (Guillet et al. 1982). Some factors can explain fast development of the use of B.t.i, which was introduced in routine larviciding against black flies and mosquitoes in the large programs OCP (Hougard \& Back 1992) and KABS (Becker 1997), respectively, only five years after its discovery: (a) high efficacy against target species, causing catastrophic larval mortality in $24 \mathrm{~h}$; (b) selectivity; (c) ability to be produced in large scale by fermentation; (d) a large knowledge base due not only to the previous use of B.t against agricultural pests but also to the recognition of its advantages for vector control by scientists; (e) the urgent need of 
an alternative, safe larvicide for use in the OCP, and collaboration between World Health Organization and industry for the development of commercial formulations (Back \& Barbazan 1994).

In OCP and later in other programs, B.t.i was adopted to assure the sustainability of the programme, as stated by Guillet et al. (1990): "Without this pathogen, the OCP would have faced very serious difficulties, especially following the extension of resistance. Ten years ago, a similar situation would have been considered a dead end recalling to some extend the failure of the Malaria Eradication Programme".

More selective than B.t.i, B.s is specially toxic to Culex and Anopheles larvae, and is very tolerant to high levels of organic pollution. Its efficacy as a biological control agent has been confirmed in several programs and large scale trials in tropical and temperate countries (Karch et al. 1992, Hougard et al. 1993, Sinègre et al. 1993, Kumar et al. 1994, Barbazan et al. 1997, Yadav et al. 1997).

\section{B.T.I AGAINST BLACK FLIES IN BRAZIL}

Two large programmes are currently using B.t.i to control black flies in Brazil, both located in areas where transmission of onchocerciasis has not been recorded. The Simuliidae Control Programme (SCP) in Rio Grande do Sul was a pioneer in the use of B.t.i in Brazil, starting in 1983, to manage the resistance to temephos recorded in $S$. pertinax populations (Ruas Neto 1984). B.t.i became the only larvicide used since then in 116 counties, to reduce the biting nuisance caused by black flies (Mardini 1998). The SCP of the Health Secretariat in the State of São Paulo is carried out in four districts, whose economy is dependent on tourism, along the Serra do Mar coastal mountain range. Having S. pertinax as the main target, the programe started replacing temephos by B.t.i in 1986, after the appearance of resistance to temephos in black fly populations has been reported. Since 1990 this programme is based on the exclusive use of B.t.i (Araujo-Coutinho 1995). No resistance to this entomopathogen in S. pertinax populations has been recorded.

\section{MOSQUITO CONTROL}

Despite all the past examples of resistance to chemical insecticide in mosquito populations, the major vector control programme currently implemented in Brazil, the PEAa - Programme for Eradication of Aedes aegypti, was launched in 1997 to fight dengue fever transmission, based on temephos as the only larvicide, as well as adulticides. In fact, the use of biological agents to control mosquitoes in Brazil has been restricted to experimental and operational research. Works developed by research teams from Oswaldo Cruz Foundation (Fiocruz), Cenargen/Embrapa and few universities have made a significant contribution to this subject through search and isolation of interesting new strains of B.s (Rodrigues et al. 1998, Silva et al. 1998), new product development and the implementation of field trials of Bacillus efficacy against mosquito species under different environmental conditions.

In terms of product development, nine experimental formulations have been submitted for evaluation under field or simulated field conditions against $C$. quinquefasciatus and $A$. aegypti in our department. Simulated field conditions allow comparison of larvicidal activity and persistence of products, once test replicates show good reproducibility (Thiéry et al. 1999, Silva 2000). To give some examples, the B.t.i tablet experimental formulation C4P1-T, showed good persistence, killing more than $70 \%$ of $A$. aegypti larvae within 40 days after treatment of tanks in shade, and 25 days in tanks exposed to sunlight. B.s formulations showed up to 100 days persistence against $C$. quinquefasciatus larvae after the third application in shaded tanks, as did a B.t.i formulation, Inpalbac, after the 4th treatment. Tested under identical conditions, some of the experimental formulations revealed performances almost or equally as good as the best commercial products tested, VectoBac- $\mathrm{G} B$ and VectoLex-G® .

Pilot field tests carried out using different products against mosquitoes in Brazilian urban areas provided operational information useful to implementing larger programes based on microbial larvicides (Table).

\section{PERSPECTIVES}

Based on the knowledge available after two decades of research and operational use of B.s and B.t.i worldwide, these products are able to replace with advantages synthetic insecticides wherever the use of a larvicide is recommended for mosquito control. This includes situations where a rapid response is needed, as in the recent outbreak of the West Nile virus transmitted by $C$. pipiens in New York city, where a B.s formulation was used, following aerial adulticiding (Ninivaggi 1999). Of course, larviciding is only one of the intervention measures to be integrated within environmental management, physical measures (such as polystyrene bead layers in cesspits) and classical biocontrol agents. In programmes based on B.s as larvicide, other control agents should be associated to avoid resistance development (Charles et al. 2000, Regis $\&$ Nielsen-LeRoux 2000). The choice of efficient and safe tools is not enough; control interventions must be sustained if the population is to be prevented from recovering. 


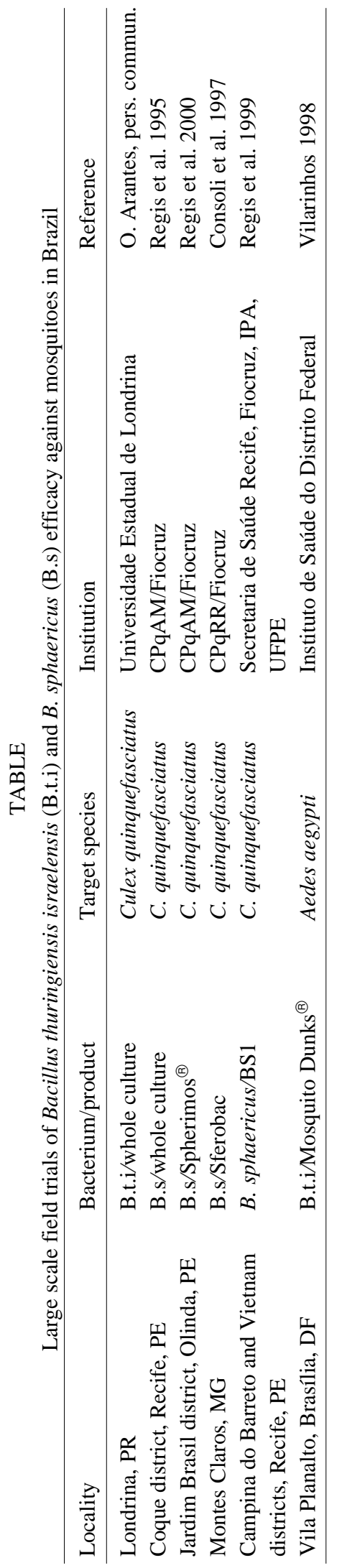

Recently, the health authorities responsible for the PEAa decided to replace temephos by B.t.i aiming to manage $A$. aegypti resistance detected in the State of Rio de Janeiro. On the other hand, B.s was the chosen larvicide for vector control to be launched this year by the Brazilian Programme for Elimination of Lymphatic Filariasis.

\section{REFERENCES}

Araújo-Coutinho CJPC 1995. Biological control program against simuliids in the State of São Paulo, Brazil. Mem Inst Oswaldo Cruz 90: 131-133.

Back C, Barbazan P 1994. Bacterial control in Africa using B.t.i and B. sphaericus against Simuliidae and Culicidae. Proc VI Int Coll Invert Pathol Microb Control, Montpellier, France, p. 254-258.

Barbazan P, Baldet T, Darriet F, Escaffre H, Haman Djoda D, Hougard JM 1997. Control of Culex quinquefasciatus (Diptera: Culicidae) with Bacillus sphaericus in Maroua, Cameroon. J Am Mosq Control Assoc 13: 263-269.

Becker N 1997. Microbial control of mosquitoes: management of the Upper Rhine mosquito population as model programme. Parasitol Today 13: 485-487.

Charles JF, Silva-Filha MHNL, Nielsen-Leroux C 2000. Mode of action of Bacillus sphaericus on mosquito larvae: incidence on resistance. In JF Charles, Entomopathogenic Bacteria: from Laboratory to Field Application, Kluwer Academic Publishers, Dordrecht, p. 237-249.

Consoli RAGB, Santos BS, Lamounier MA, Secundino NFC, Rabinovitch L, Silva CMB, Alves RSA, Carneiro NFF 1997. Efficacy of a new formulation of Bacillus sphaericus 2362 against Culex quinquefasciatus (Diptera: Culicidae) in Montes Claros, Minas Gerais, Brazil. Mem Inst Oswaldo Cruz 92: 571-573.

de Barjac H 1978. Une nouvelle variété de Bacillus thuringiensis très toxique pour les moustiques: $B$. thuringiensis var israelensis sérotype H14. CR Acad Sci Paris 286: 797-800.

Goldberg LY, Margalit J 1977. A bacterial spore demonstrating rapid larvicidal activity against Anopheles sergentii, Uranotaenia unguiculata, Culex univittatus, Aedes aegypti and Culex pipiens. Mosq News 37: 355-358.

Guillet P, Escaffre H, Ouedraogo M, Quillevere D 1982. L'utilisation d'une formulation à base de Bacillus thuringiensis $\mathrm{H} 14$ dans la lutte contre l'onchocercose en Afrique de l'ouest. Part 2, Stabilité dans les conditions de stockage em milieu tropical. Cad ORSTOM sér Ent Med et Parasitol 20: 181-185.

Guillet P, Kurstak DC, Philippon B, Meyer R 1990. Use of Bacillus thuringiensis israelensis for Onchocerciasis Control in West Africa. In H de Barjac, DJ Sutherland (eds), Bacterial Control of Mosquitoes and Blackflies, Rutgers Univ Press, New Jersey, p. 187-199.

Hougard J-M, Back C 1992. Perspectives on the bacteriological control of vectors in the tropics. Parasitol Today 8: 364-366.

Hougard J-M, Mbentangam R, Lochouarn L, Escaffre 
H, Darriet F, Barbazan P, Quillévéré D 1993. Control of Culex quinquefasciatus by Bacillus sphaericus: results of a pilot campaign in a large area in Equatorial Africa. Bull WHO 71: 367-375.

Karch S, Asidi N, Manzambi M, Salaun JJ 1992. Efficacy of Bacillus sphaericus against the malaria vector Anopheles gambiae and other mosquitoes in swamps and rice fields in Zaire. J Am Mosq Control Assoc 8: 376-380.

Kellen WR, Meyers CM 1964. Bacillus sphaericus Neide as a pathogen of mosquitoes. J Invertebr Pathol 7: 442-448.

Kumar A, Sharma VP, Sumodan PK, Thavaseluam D, Kamat RH 1994. Malaria control utilising Bacillus sphaericus against Anopheles stephensi in Pinaji, Goa. J Am Mosq Control Assoc 10: 534-539.

Mardini LBLF 1998. Programa estadual de controle biológico do Simulium sp. (Diptera: Simuliidae) no Rio Grande do Sul. Anais do IV Simpósio de Controle Biológico, Rio de Janeiro, p. 41-43.

Ninivaggi DV 1999. West Nile virus in New York city: the initial response. Wing Beats Fall: 29-31.

Regis L, Nielsen-LeRoux C 2000. Management of resistance to bacterial vector control. In JF Charles, Entomopathogenic Bacteria: from Laboratory to Field Application, Kluwer Academic Publishers, Dordrecht, p. 419-441.

Regis L, Silva-Filha MHNL, Oliveira CMF, Rios EM, Silva SB, Furtado AF 1995. Integrated control measures against Culex quinquefasciatus, the vector of filariasis in Recife. Mem Inst Oswaldo Cruz, 90: 115119.

Regis L, Silva-Filha MHNL, Oliveira CMF, Silva SB, Furtado AF 2000. Efficacy of Bacillus sphaericus in control the filariasis vector Culex quinquefasciatus in an urban area of Olinda, Brazil. Trans $R$ Soc Trop Med Hyg 94 (in press).

Regis L, Silva SB, Maranhão LMC, RIOS EM, Carieli MA 1999 Avaliação da eficácia e viabilidade do uso de larvicida à base de Bacillus sphaericus, produzido localmente, no controle de Culex quinquefasciatus em áreas do Recife, (Report), Fiocruz/CPqAM, Recife, 19 pp.

Rodrigues IB, Tadei WP, Dias JMCS 1998. Studies on the Bacillus sphaericus larvicidal activity against malarial vector species in Amazônia 1998. Mem Inst Oswaldo Cruz 93: 441-444.

Ruas Neto AL 1984. Bacillus thuringiensis var. israelensis como alternativa no controle de simulídeos no Rio Grande do Sul. 1. Susceptibilidade a campo. B Saúde, Porto Alegre, 11: 21-26.

Silva KRA, Meirelles MNSL, Rabinovitch L 1998. U1trastructural and entomotoxic aspects of Bacillus sphaericus strains isolated from Brazilian soils. Israel J Entomol 32: 147-154.

Silva SB 2000. Avaliação de Produtos à Base de Bactérias Entomopatógenas para o Controle do Vetor da Filariose Linfática, Culex quinquefasciatus (Diptera:Culicidae), MSc Thesis, Universidade Federal de Pernambuco, Recife, 92 pp.

Sinègre G, Babinot M, Vigo G, Jullien J-L 1993. Bacillus sphaericus et démoustication urbaine. Bilan de cinq années d'utilisation expérimentale de la spécialité Spherimos® dans le sud de la France. Entente Interdépartementale pour la Démoustication du Littoral Méditerranéen, Document no. 62, 21 pp.

Thiéry I, Fouque F, Gaven B, Lagneau C 1999. Residual efficacy of $B$. thuringiensis subsp. medellin and jegathesan on Culex pipiens and Aedes aegypti larvae. J Am Mosq Control Assoc 15: 371-379.

Vilarinhos PTR 1998. Controle de culicídeos urbanos com bactérias entomopatogênicas. Anais do VI Simpósio de Controle Biológico, Rio de Janeiro, Brasil, p. 441-444.

Yadav RS, Sharma VP, Upadhyay AK 1997. Field trial of Bacillus sphaericus strain B-101 (serotype H5a,5b) against filariasis and Japanese encephalitis vectors in India. J Am Mosq Control Assoc 13: 158-163. 